\title{
Prevalence of Learning Disabilities among Pre-School Children in Faizabad District (Uttar Pradesh)
}

\author{
Pratibha $^{1}$, Mukta Garg ${ }^{2}$ \\ ${ }^{1,3}$ Research Scholar \\ ${ }^{2}$ Head of the Department
}

\begin{abstract}
Learning disability" is defined and a line is drawn between learning dis- abilities and school difficulties resulting from other causes such as inadequate school management, lack of well-trained and effective teachers in the schools, large class sizes, providing early primary education in an international language that is not the child's mother tongue, lack of teaching materials, and unfortunately - still - sometimes negative attitudes among some teachers toward children with disabilities and their inclusion in regular schools as a result of teachers' traditions and culture, as described by Abosi (2007). A study was carried out assess the Prevalence of learning Disabilities among Pre-school Children in Faizabad District. The study also focused on causes of learning disabilities among pre-school children. For the present study total sample of 60 pre -school children are selected using random sampling technique were selected from the faizabad district. Study was found that the majority of parental carelessness and child illness are major causes of learning disabilities of children. And majority of problems in found that the mathematical problems are most prevalent learning disability in pre-school children.
\end{abstract}

Keywords: Learning disability reading (dysgraphia), Reading (dyslexia), mathematics (dyscalculia)

\section{Introduction}

Learning disability is a classification that includes several areas of functioning in which a person has difficulty learning in a typical manner, usually caused by an unknown factor or factors. Given the "difficulty learning in a typical manner", this does not exclude the ability to learn in a different manner. Therefore, some people can be more accurately described as having a "Learning Difference", thus avoiding any misconception of being disabled with a lack of ability to learn and possible negative stereotyping.

While learning disability, learning disorder and learning difficulty are often used interchangeably, they differ in many ways. Disorder refers to significant learning problems in an academic area. These problems, however, are not enough to warrant an official diagnosis. Learning disability on the other hand, is an official clinical diagnosis, whereby the individual meets certain criteria, as determined by a professional (psychologist, pediatrician, etc.). The difference is in degree, frequency, and intensity of reported symptoms and problems, and thus the two should not be confused. When the term "learning disorder" is used, it describes a group of disorders characterized by inadequate development of specific academic, language, and speech skills. Types of learning disorders include reading (dyslexia), mathematics (dyscalculia) and writing (dysgraphia).

A learning disability is a neurological disorder. In simple terms, a learning disability results from a difference in the way a person's brain is "wired." Children with learning disabilities are as smart as or smarter than their peers. But they may have difficulty reading, writing, spelling, and reasoning, recalling and/or organizing information if left to figure things out by them or if taught in conventional ways. A learning disability can't be cured or fixed; it is a lifelong issue. With the right support and intervention, however, children with learning disabilities can succeed in school and go on to successful, often distinguished careers later in life Parents can help children with learning disabilities achieve such success by encouraging their strengths, knowing their weaknesses, understanding the educational system, working with professionals and learning about strategies for dealing with specific difficulties.

\begin{abstract}
"School learning is affected by many factors. The personal characteristics of the child, familial attributes, and factors related to the school and class altogether affect the child's ability and potential to benefit from teaching. These factors influence the child's learning experiences and in the process affect the child's self-image as a learner, among many other attributes. These experiences, the child's beliefs, and his/her knowledge and skills, together with the characteristics of the environment, form a complex interactional system. Understanding this sys- tem helps us to understand the underlying factors in children's learning difficulties which is a prerequisite for planning and implementing effective pedagogical and intervention strategies.
\end{abstract}

Weaknesses in these skills can create a drain on students' abilities to generate text and can impair their motivation to write (Graham and Perin, 2007) Some common characteristics of struggling writers (Berninger and Amtmann, 2003; Graham and Perin, 2007) are: poor handwriting; - poor spelling (which may be associated with word decoding problems in reading); - poor use of basic mechanics (e.g., capitalization or punctuation); • difficulties with text-generation aspects of writing such as poor word choice, lack of - elaboration or detail, poor organization of content, and lack of clarity (which are some- times, but not always, associated with oral language weaknesses such as limitations in vocabulary or grammatical weaknesses); failure to use planning process 


\section{International Journal of Science and Research (IJSR) \\ ISSN (Online): 2319-7064 \\ Index Copernicus Value (2013): 6.14 | Impact Factor (2014): 5.611}

in writing; - a reluctance to revise and edit writing, difficulty recognizing errors, or lack of knowledge • of how to correct errors; and lack of motivation to write (often because the process of getting ideas on paper is per- ceived as laborious). The approach to writing taken by students with learning disabilities often focuses on generating content but includes little planning, monitoring and evaluating: "Little effort is made to evaluate or rework [these] ideas or to consider the constraints imposed by the topic, the needs of the audience, or the organization of text. The resulting composition is generally a list of topicrelated ideas rather than a coherent discussion or examination of the topic" (Graham and Harris, 2003, p. 324). Another characteristic of writing of students with learning disabilities is low production. Graham and Harris (2003) provide related reasons: difficulty sustaining the writing effort, failure to access what is known about a topic, and difficulty with the process of generating content due to interference of the mechanics of writing.

\section{Causes of a learning disability}

Learning disabilities are caused by something affecting the development of the brain. This may occur before birth (prenatally), during birth, or in early childhood. Learning disabilities can be caused by any one of a variety of factors, or by a combination. Sometimes the specific cause is not known. Possible causes include the following:

- An inherited condition, meaning that certain genes passed from the parents affected the brain development, for example Fragile X

- Chromosome abnormalities such as Down's syndrome or Turner syndrome

- Complications during birth resulting in a lack of oxygen to the brain

- A very premature birth

- Mother's illness during pregnancy

- The mother drinking during pregnancy, for example Foetal Alcohol Syndrome

- A debilitating illness or injury in early childhood affecting brain development, for example a road traffic accident or child abuse

- Contact with damaging material (like radiation)

- Neglect, and/or a lack of mental stimulation early in life.

Some people with learning disabilities have additional physical disabilities and/or sensory impairments.

\section{Common Learning Disabilities}

- Dyslexia - a language-based disability in which a person has trouble understanding written words. It may also be referred to as reading disability or reading disorder.

- Dyscalculia - a mathematical disability in which a person has a difficult time solving arithmetic problems and grasping math concepts.

- Dysgraphia - a writing disability in which a person finds it hard to form letters or write within a defined space.
- Auditory and Visual Processing Disorders - Sensory disabilities in which a person has difficulty understanding language despite normal hearing and vision.

- Nonverbal Learning Disabilities - A neurological disorder which originates in the right hemisphere of the brain, causing problems with visual-spatial, intuitive, organizational, evaluative and holistic processing functions

\section{Materials and Method}

\section{Research design}

Research design is a coherent plan in conducting research, which deals with structure and strategy of investigation so conceived to obtain answers to research questions. Research designs are used conduct research with objectivity and accuracy. (Kerlinger 1995).

1. Local of the study: The study will we conducted at faizabad district as the researcher is acquainted and familiar with the place.

2. Sample selection: faizabad district was purposively selected for the study as the researcher was familiar with the place. Various schools of faizabad district will be selected using random sampling technique to draw the sample. Children in to the age group of 2-5 years.

3. Criteria for selection of sample: Children in the age group of 7-12 years and their parents belonging to the lower, middle and upper socio economic status families were selected to study the child abuse.

\section{Results and Discussion}

Table 1: Percentage distribution of children who showing different types of learning disabilities

\begin{tabular}{|c|c|c|}
\hline Learning disability & $\begin{array}{c}\text { Total number of } \\
\text { learning disabled } \\
\text { children } 60\end{array}$ & Percentage \\
\hline Reading & 20 & 33.33 \\
\hline Writing & 15 & 25 \\
\hline Arithmetic & 25 & 41.67 \\
\hline
\end{tabular}

Result in the table revealed that the majority (41.67\%) of the children exhibited arithmetic problem fallowed by the group of children showing disability in reading (33.33\%) writing emerged as least prevalent learning disability in (25\%) children only. Similar finding was also supported by Torbeyns et. al. (2004) those mathematical problems are most prevalent learning disability in pre -school children.

Table 2: Percentage distribution of age at which children started showing their learning disabilities

\begin{tabular}{|c|c|c|}
\hline \multirow{2}{*}{ Age } & $\begin{array}{c}\text { Total No of child } \\
60\end{array}$ & Percentage \\
\hline 2 year & 7 & 11.67 \\
\hline 3 year & 23 & 38.33 \\
\hline 4 year & 17 & 28.33 \\
\hline 5 year & 13 & 21.67 \\
\hline
\end{tabular}




\section{International Journal of Science and Research (IJSR) \\ ISSN (Online): 2319-7064 \\ Index Copernicus Value (2013): 6.14 | Impact Factor (2014): 5.611}

Indicate that the maximum (38.33\%) children showing their learning disability from the age of 3 year fallowed by the group of children who exhibited learning disability from the 4 year (28.33\%) and then remaining showed from the 5 year $(21.67 \%)$ and least number of children showing learning disability from the age of 2 year (11.67)

Table 3: Percentage distribution of the causes of learning disabilities in children as reported by the teachers

\begin{tabular}{|c|c|c|}
\hline $\begin{array}{c}\text { Learning disabled } \\
\text { children }\end{array}$ & $\begin{array}{c}\text { Total number of disabled } \\
\text { child NO-60 }\end{array}$ & Percentage \\
\hline Both parents working & 9 & 15 \\
\hline Divorce & 7 & 11.67 \\
\hline Child illness & 10 & 16 \\
\hline Death of a parent & 6 & 10 \\
\hline Parental carelessness & 10 & 16 \\
\hline illiteracy & 9 & 15 \\
\hline Child weak & 8 & 13.33 \\
\hline
\end{tabular}

Revealed that the teachers reported that parental carelessness and child illness are the major factors of the learning disability. The majority $16 \%$ and $16 \%$ respectively, cases which was also reported by learner (1987) teachers also considered illiteracy the second major cause of learning disability in children $15 \%$ as was also reported by nagligeri et. al, (1990) In the same case teacher taught the problem occurred because the both parents are working (15\%) Some of the teachers also reporting various others factors for learning disability like divorce, $(11.67 \%)$ death of a parent $10 \%$ and child weak (13.33\%)

\section{References}

[1] Abosi, O. (2007). Educating children with learning disabilities in Africa. Learning Disabilities Research \& Practice, 22, 196-201.

[2] Graham, S., and Perin, D. (2007). Writing next: Effective strategies to improve writing of adolescents in middle and high schools - A report to Carnegie Corporation of New York. Washington, DC: Alliance for Excellent Education.

[3] Graham, S., and Harris, K. R. (2003). Students with learning disabilities and the process of writ- ing: A meta-analysis of SRSD studies. In H. L. Swanson, K. R. Harris, and S. Graham (Eds), Handbook of Learning Disabilities (pp. 323-344). New York: Guilford.

[4] Berninger, V. W., and Amtmann, D. (2003). Preventing written expression disabilities through early and continuing assessment and intervention for handwriting and/or spelling problems: Research into practice. In H. L. Swanson, K. R. Harris, and S. Graham (Eds.), Handbook of Learning Disabilities (pp. 345-363). New York: Guilford.

[5] Dudley-Marling, Curt (2004). "The Social Construction of Learning Disabilities". Journal of Learning Disabilities 37 (6): 482-489. doi:10.1177/00222194040370060201.

[6] Ho, Anita (June 2004). "To be labelled, or not to be labelled: that is the question". British Journal of Learning Disabilities $32 \quad$ (2): $\quad 86-92$. doi:10.1111/j.1468-3156.2004.00284.x.
[7] Williams, Val; Heslop, Pauline (May 2005). "Mental health support needs of people with a learning difficulty: a medical or a social model?". Disability \& Society $20 \quad$ (3): $231-245$. doi:10.1080/09687590500060554

[8] National Research Center on Learning Disabilities (NRCLD)". Retrieved 2010-05-01.

[9] Reiff, Henry B.; Gerber, Paul J.; Ginsberg, Rick (Spring 1993). "Definitions of Learning Disabilities from Adults with Learning Disabilities: The Insiders' Perspectives". Learning Disability Quarterly 16 (2): 114-125. doi:10.2307/1511133 